\title{
INTERAKTÍV TESZTEK A TUDÁSSZINT MÉRÉSÉRE
}

Szerző:

Pšenáková Ildikó (PhD)

Trnavská univerzita v Trnave (Szlovákia)

Szerző e-mail címe:

ildiko.psenakova@gmail.com
Lektorok:

\author{
Szabó Tibor (PhD) \\ Univerzita Konštantína Filozofa v Nitre \\ (Szlovákia) \\ Szabóné Balogh Ágota (PhD) \\ Gál Ferenc Főiskola \\ ...és további két anonim lektor
}

\begin{abstract}
Absztrakt
Az oktatási folyamat kitűzött céljainak teljesítését és ellenőrzését a pedagógiai mérések segítik. Az interaktív teszteket az egyre gyakrabban használt tudásmérő eszközök közé sorolhatjuk. Ez a tesztelő módszer a tanárok és a diákok számára is számos előnnyel jár. Cikkünkben bemutatjuk az IKT eszközök szerepét a tudásszint mérésében és néhány az interaktív tesztek létrehozása alkalmazható szoftvert is jellemzünk. Egy kísérlet eredményei erejéig kitérünk a stressz hatására is a tesztelt személyre.
\end{abstract}

Kulcsszavak: interaktivitás, tudás, teszt, értékelés

Diszciplína: pedagógia

\section{Abstract \\ INTER ACTIVE TESTS FOR MEASURING THE LEVEL OF KNOWLEDGE}

The achievement and control of the objectives of the educational process are supported by pedagogical measurements. Interactive tests can be categorized as tools for measuring knowledge. This test method has many benefits for teachers and students. In our article, we present the role of ICT tools in measuring the level of knowledge, and some of the softwares for the creation of interactive tests are characterized. We briefly intend to present our results of one of the experiments of individuals tested under the influence of stress.

Keywords: interactivity, knowledge, test, evaluation Discipline: pedagogy

Pšenáková Ildikó (2019): Interaktív tesztek a tudásszint mérésére. OxIPO - interdis₹ziplináris tudományos folyóirat, 2019/1, 85-93. doi: 10.35405/OXIPO.2019.1.85 
A személyi számítógépek ma már az oktatás szinte nélkülözhetetlen eszközei közé tartoznak. Egyaránt segítik a tanárokat munkájukban és a diákokat a tanulásban. A számítógépet az iskolában és otthoni környezetben is lehet felkészülésre, tanulásra használni, mindig rendelkezésre áll, nem fárad el, nem kifogásolja, ha többször néz meg egy leckét a diák, nem számolja mennyi időt vesz igénybe a felhasználó egy-egy feladat megoldásához. De ha éppen arra van szükség, hogy a felaladatok (teszt) megoldásához be kell tartani bizonyos meghatározott időintervalumot a "gép" azt is megtudja oldani.

Hasonlóképen a számítógépekhez a modern didaktikai eszközök közé sorolhatjuk az interaktív tábla különböző fajtáit is, amelyek manapság már minden iskolában jelen vannak. A számítógépek és interaktív táblák bevezetésének az oktatásba és használatuknak az elsődleges célja az oktatási folyamat javítása, modernizálása.

Az interaktív táblák használata a tanárok számára új formát jelent a tananyag bemutatásához, valamint lehetőséget ad érdekes és vonzó gyakorlatok, feladatok létrehozására és felhasználására. A tanítás a tanulók számára érdekesebbé válik. Az interaktivitás jól kihasználható különböző tan-tárgyak oktatásában, és szintén fontos az autonóm nyelv és az idegen nyelv oktatásának fejlesztésében, miközben hozzájárul a tanítás individualizálásához (Godiš, 2017). Az interaktivitás segít a tanulók tudásszintjének vizsgálatában, mérésében is, ami ez által kevésbé stresszes, hatékonyabb és az értékelése elfogulatlanabb. Az interaktivitás a tanuló számára minden esetben valamilyen visszacsatolást is jelent, ami közvetetten befolyásolja a tanulási folyamat hatékonyságát. A visszacsatolásnak nemcsak a folyamat szabályozásában van szerepe, hanem értékelési funkcióval is rendelkezhet s így jól használható a tesztelésben is.

\section{A tudásszint mérése}

Minden oktatási folyamat megköveteli a kitűzött célok teljesítésének mérését és ellenőrzését. A pedagógiai mérések a tanulók/diákok és a tanítók/tanárok számára az egyik visszajelző eszköz.
A tudásszint vizsgálatok eredményei fontosak mindkét érdekelt fél számára, ezért az eredményeket szakmailag megfelelően kell értelmezni, érzékenyen kezelni és az értékelésben megfelelően használni.

A tanulók tudásszintjének azonosítására és értékelésére számos módszert ismerünk. Hogy mikor melyik módszer éppen a megfelelő, melyiket válaszszuk, különböző döntő fontosságú feltételeket kell figyelembe venni:

- az értékelés célja: folyamatos értékelés (főleg diagnosztikai szerepet végez) vagy összegző értékelés (a befejezett tanítás egyenlege),

- a kimenet formája (jel, pontok, százalékok),

- azértékelt tanulók száma,

- a rendelkezésre álló idó a tudás szintjének meghatározására és az eredmények feldolgozására,

- az eszközöök és eróforrások (emberi és technikai) amelyek rendelkezésre állnak (Burjan, 2003).

A feltételek jellegétől függően meg lehet határozni a megfelelő módszert és a tudásszint vizsgálatának típusát, a szóbeli vizsgáktól, írásbeli, írásos vagy elektronikus teszteken át egészen az interaktív feladatok megoldásáig.

Az interaktív teszteket a tanulók tudásszintjének felmérésére az egyre gyakrabban használt eszközök közé sorolhatjuk. A tanárok számára ez a tesztelő módszer számos előnnyel jár, például egyszerúsíti a tesztek értékelését. A diákok számára az interaktív tesztelés lehetôvé teszi, hogy a válaszadás utáni visszajelzésekkel azonnal megtudják és megtanulhatják a helyes választ, és ezzel is javulhat a tudás szintjük. A tesztek eredményeihez nemcsak a tanuló/diák, hanem a tanár is azonnal hozzáférhet, és így azok alapján viszonylag megbízhatóan megtudja határozni a tanulók tudásszintjét. Ehhez azonban a teszteket úgy kell megtervezni, hogy a diákok számára érthetók legyenek az egyes feladatok és tudásuk szintjének megfelelóen tudjanak válaszolni rájuk. Nem elhanyagolható tény az sem, hogy a kérdések azt teszteljék, amire szükség van, hogy a tanár a válaszokból megtudja elsajátították-e a diákok az elvárt tudást. 


\section{Az interaktív tesztelés}

Az alábbiakban az interaktív tesztelést a következő képen fogjuk értelmezni: $A$ z interaktiv tesztelés egy modern, progresszív és gyors módszer a diákok tudásszintjének ellenörzésére és mérésére olyan szoftver segitségével, amely folyamatosan értékeli a tesztelt ismereteket és visszajelzésekekel korrigálja a diákok lehetséges hibás feltételezéseit, illetve a tévbiteket.

Az interaktív tesztelés nélkülözhetetlen eszköze a személyi számítógép vagy más számítógépes technológiák használata, ezért az interaktív tesztelés számítógépes tesztelés típusának is minősülhet, amelynek vannak előnyei, de hátrányai is.

Saját tapasztalatok és több szerző (Pšenáková, 2016; Pšenáková, Horváth és Szabó, 2016; Ďuriš és Stadtrucker, 2013; Stoffová, 2012; Cápay, 2006) alapján a következőket sorolhatjuk az interaktív tesztelés előnyei közé:

- magasabb hatékonyság (rövidebb idő alatt több hallgatót lehet tesztelni és értékelni),

- rugalmasság (flexibilitás) - a tesztelés nagyobb csoportoknak és különböző helyeken is folyhat egyidejűleg,

- papírnélküli tesztelés (környezetbarát tesztelés) - szintén emeli a flexibilitást,

- azonnali értékelés és visszajelzés - a hallgató közvetlenül a teszt befejezése után megtudja az eredményt,

- az értékelés nagyobb objektivitása - az interaktív tesztelés mindenkinek egyforma feltételek nyújt,

- a pedagógus terhelésének csökkentése - a teszteket nem szükséges kinyomtatni, igy időt lehet megtakarítani és az összeállitásuknál is jó pár óra megspórolható, a teszt befejezése után a vizsgálati eredmények is azonnal rendelkezésre állnak, így a tanárt nem terheli a tesztek javítása és objektív értékelése,

- a kérdések és feladatok nagy változatossága és gyakorisága,

- a tesztfeladatok hanggal, videóval vagy animációval gazdagíthatók, ami javíthatja a hitelességüket,

- a diák kísérleteiről és tevékenységéről szóló információk megőrzése,
- népszerűség - a tesztek és értékelésük ebben a formában vonzóbb a diákok körében,

- lehetőség az eredmények archiválására.

Hasonló tapasztalatok alapján a számítógépes, illetve interaktív tesztelés hátrányaiként többek között az alábbiakat lehet megemlíteni (Pšenáková, 2016; Stoffová, 2012; Cápay, 2006):

- a számítástechnika eszközei és a kommunikációs technológia szükségessége - vannak még iskolák ahol nem megfelelő az iskola felszereltsége, illetve szükséges az eszközök kiegészitése és frissítése, hogy az interaktív tesztelés hatékonyabb és tárgyilagosabb legyen,

- az interaktív tesztelés korlátozása egy tudásterületre - az alkotók a tesztekben gyakran csak strukturált kérdéseket használnak, amelyekben a diák a megadott feleletekből választ és nem kényszerül arra, hogy gondolkodjon a tudásról,

- kevesebb lehetőség saját gondolatok és vélemények kifejtésére a válaszokban a tesztelt kérdésekre - mivel az interaktív teszt nem tudja könnyen feldolgozni és értékelni a strukturálatlan kérdéseket, amelyekre a diákok saját szavaikkal válaszolhatnak,

- a szociális/társadalmi kapcsolatok és a nevelési befolyás hiánya - az oktatásban és nevelésben a diákokat fontos a hatékony kommunikációra tanítani, hogy beszéljenek a problémákról és képesek legyenek elfogadni a kritikát. A tanuló csak akkor szerezheti meg ezt a képességet, ha szóban is ellenőrzi az ismereteket, mert jelenleg az ember nem tud teljes mértékben kommunikálni a számítógéppel.

- pszichomotorikus készségek korlátozása - az interaktív tesztelés nem teszi lehetôvé a megszerzett gyakorlati készségek, tapasztalatok és szokások értékelését.

A felsorolt előnyöket és hátrányokat és még sok más nem említett tényezőt kell figyelembe venni, megvizsgálni és mérlegelni abból a szempontból, hogy az interaktív tesztelés pozitív, ill. negatív jellegei megfelelnek-e az elvárt követelményeinknek és 
igényeinknek, és ezután eldönthetjük, hogy milyen típusú tudásszint-ellenőrzést használjunk. $\mathrm{Ha}$ a feladatok igazodnak a tanuló/diák potenciális teljesítményéhez, akkor a tanuló/diák kompetenciaérzése is jótékony hatással lehet a tanulási folyamat alakulására.

Szintén az előnyöket és hátrányokat mérlegelve megállapíthatjuk, hogy nem használhatjuk minden típusát a hagyományos/klasszikus didaktikai tesztek-ben alkalmazott feladatoknak. Az interaktív tesztelésben leggyakrabban a következő típusú feladatokat használjuk (Ďuriš és Stadtrucker, 2013):

1. Zárt végü feladatok: mivel az interaktív tesztekben elsősorban a zárt végú feladatokat használata a gyakoribb, ezért fontos megemlíteni, hogy a tanár könnyen abba a csapdába eshet, hogy túlnyomórészt ismeret típusú tudást kér számon. A zárt feladatokban a lehetőségek eleve fel vannak kínálva, ezért a tanulónak azokat már nem kell kigondolnia (Csapó és tsai., 2008). Zárt végú feladatok néhány jellegzetes típusa:

- Dichotóm feladatok - a tesztekben gyakran alkalmazzák, de az ilyen fajta kérdés azzal a kockázattal jár, hogy a diák eltalálja a választ, akkor is, ha nem tudja. Ilyen típusú feladat az olyan, amelyre a válasz lehet például: igen, nem; igaz, hamis; jó, rossz.

- Feleletválasztós feladatok - amelyekben több felkínált lehetőség közül lehet választani. A leggyakrabban használt tesztfeladatok közé tartoznak. A válaszok nemcsak szövegek lehetnek, hanem képek is. A válaszok között lehet több helyes válasz is, de a legmegfelelőbbek azok a kérdések, amelyeknek csak egy helyes válaszuk van.

- Elrendezési feladatok - amelyekben a fogalmakat (melyek például mondatok, szavak, kifejezések, képek formájában vannak köz-readva) egy meghatározott feltétel (kritérium) szerint helyes sorrendbe kell rendezni.

- Hozzárendelési feladatok - az egyik csoport fogalmait kell hozzárendelni a másik cso- portban található kapcsolódó fogalmakhoz vagy képekhez.

2. Nyillt végú feladatok: ezek eredménye (a tanuló által adott output) lehet például egy szó, szám, képlet, stb., ezért a válasz rövid, strukturált. A nyílt végú feladatoknál a feladatmegoldás része az is, hogy a válaszadó megértse, milyen választ várnak tőle.

Hogy ezeket a típusú feladatokat milyen formában „tálaljuk” a diákok elé az a tanár kreativitásától, informatikai készségeitôl és a készítésre használt szoftver lehetôségeitôl is függ. A gyakorlatban a legkedveltebbek között találjuk a memóriajátékokat, puzzle és keresztrejtvény típusú megoldásokat.

A modern tesztelmélet számos előnnyel rendelkezik a klasszikussal szemben. Egyrészt az egyes feladatok eredményeit is lehet mérni, nem csak a teljes teszttét, így a tanárnak egy kérdés vagy egy teszt megvalósítása után sokkal pontosabb képet kap az osztály/csoport valós tudásszintjéről.

\section{Az IKT eszközök \\ szerepe a tudásszint mérésében}

A számítógép és infokommunikációs eszközök hatékonyan használhatóak a tanulási folyamat minden szakaszában, a motivációtól kezdve, a tananyag elsajátításán és elmélyítésén át, egészen a tudásszint felméréséig és a hallgató értékeléséig.

Az IKT eszközok, köztük az interaktív tábla használata a tanártól szinte megköveteli a régebben kialakult tanítási módszereinek és szokásainak újítását és átalakítását. Ez a folyamat nem kevés energiát és idôt vesz igénybe. Nem minden tanár rakja szívesen félre a régi, sok éven át használt, jól bevált módszereket és tanítási gyakorlatokat, és neki fog újakat, az IKT eszközöket kihasználó módszereket fejleszteni. Mindeznek ellenére a gyakorlatban számos pozitív példát is láthatunk, amelyekben a tanárok aktívan használják az IKT eszközöket az oktatás folyamán, beleértve az interaktív táblát is.

Bármely tanítási módszer alkalmazása esetén, szinte nélkülözhetetlen a diákok figyelme, amit igen nehéz fenntartani akkor, ha minden tanuló asztalán van egy múködő számítógép. Másrészt a tanúlóknak már az alapfokú oktatás során meg kellene 
szerezniük az IKT eszközök használatához szükséges készségeket. Emellett szükség van a nem lineáris, multimediális oktatási anyagok bemutatására is, amelyek jobban megfelelnek a különböző problémamegoldó készségek fejlesztéséhez. Az interaktív tábla lehetôvé teszi a jól ismert és jól bevált tanítási módszerek ötvözését a legújabb információs, kommunikációs és prezentációs technológiákkal, így a tanulók ezeket a készségeket viszonylag rövid idő alatt elsajátíthatják.

Sok jelenlegi számítógépes tesztelési rendszer mesterséges intelligenciával rendelkezik. Ezek nem csak a kérdések és feladatok algoritmikus kiválasztását teszik lehetôvé, de képesek ezeket a vizsgált személy tudásszintjéhez is igazítani. Ezen kívül a feladatok létrehozását és a megoldások levezetését (számítási eljárás) is a meghatározott kritériumok (feltételek), kiválasztott paraméterek és bemeneti értékek szerint vezérelhetik.

Az interaktív oktatási szoftver (beleértve a tesztelés lehetőségét is) és annak tartalmának (beleértve a teszt feladatokat is) létrehozása előtt számos kérdésre szükséges válaszolni, mint például:

- Mi az oktatási szoftver célja?

- Megfelel-e a tartalom nehézsége a tanulók, diákok korának?

- Megfelel-e a tananyag a tantervnek?

- Szakmai szempontból helyes-e a tartalom?

- Tartalmaz-e motivációs elemeket?

- Tartalmaz-e interaktív elemeket?

- Megfelelő-e a rendszer nyitottsága?

- Ad-e visszajelzést a szoftver?

Az említett követelményeknek megfelelő szoftvert létrehozni nagyon nehéz, ső́t gyakran lehetetlennek tűnik. Ezért a pedagógusok inkább el sem kezdik az ilyen rendszerek létrehozását, és előnyben részesítik a professzionális, kereskedelemben kapható szoftvereket, vagy egyáltálán nem használnak szoftvert a teszteléshez. Ennek eredményként nem veszik igénybe az IKT eszközökkel nyújtott lehetőségeket sem és továbbra is a már nekik ,jól bevált" papírformát használják.

\section{Szoftverek interaktív tesztek létrehozására}

A gyakorlatban számos programcsomag létezik, amelyek segítségével egyszerú vagy bonyolultabb módon különböző feladatokat és interaktív teszteket lehet számítógépre, interaktív táblára létrehozni a tanulók/diákok tudásszintjének tesztelésére. Nem célunk mindegyiket bemutatni, csak az általunk leggyakrabban használt és jól beváltakat említenénk.

A könnyen kezelhető, de amellett bonyolultabb, nehezebb feladatok létrehozására is alkalmas programok közé tartozik a Hot Potatoes. Ez egy ingyenes (freeware) szoftver, amely szabadon letölthető a bttps:/ / hotpot.uwic.ca/ weboldalról és bármilyen célra vagy projektre használható (1. ábra).

1. ábra: Példa HotPotatoes programban készüllt interaktív tesz̨ kérdéseiböl - angolnyelv tudás tesztelése - (forrás: a Szer:ö)

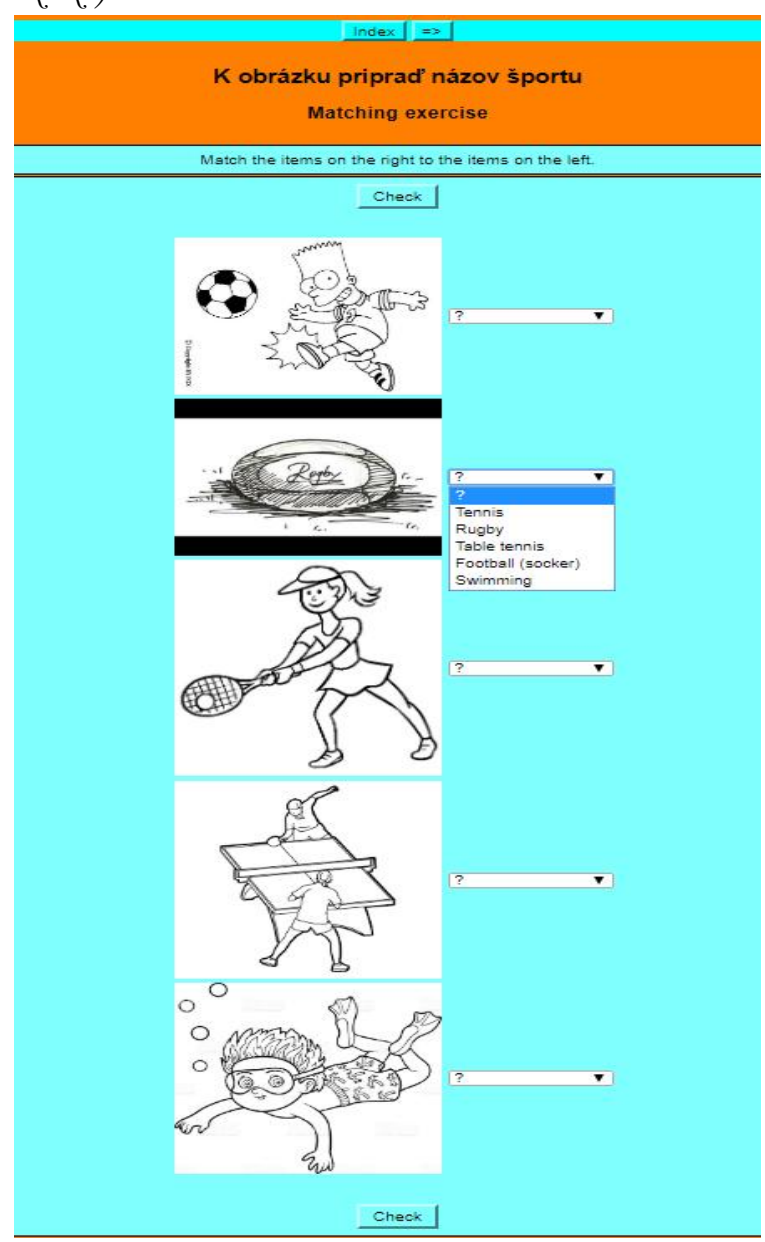


A programban a tanár különböző típusú feladatokat különböző tantárgyakhoz hozhat létre, közben használhat szövegeket, képeket, hangokat, animációkat és videókat is. A program automatikusan értékeli az eredményeket, és azokat százalékban jeleníti meg a képernyőn. A tanár belátása szerint az értékelést ki lehet egészíteni megfelelő szöveges visszacsatolással. A feladat típusától függően kisegítő szövegeket is be lehet iktatni a feladatokba, amelyek használata segíthet a feladatok megoldásában, de a szöveg igénybevételével csökken a százalék az értékelésben.

A Google számos szolgáltatást kínál a tanárok számára is az osztályterem, az anyagküldés, a házi feladat vagy a tudásvizsgálat jobb áttekintésére.
A Google 2014-ben kiegészítette a Google Forms lehetőségeit egy egyszerú felmérések és űrlapok létrehozására szolgáló funkcióval, amellyel űrlapok segítségével pontozott feladatok és visszajelzésekkel ellátott kérdések hozhatók létre. A Forms ingyenes, többfunkciós, folyamatosan növekvő szoftver és tapasztalataink alapján jól használható a diákok teszteléshez.

A teszt készítője különböző típusú grafikai felület (sablon) és számos kérdésfajta (feleletválasztós, legördülő menü, szöveges karakterlánc vagy akár lineáris skála) közül választhat (vö.: 2. ábra). A tesztbeállitásoknál lehetôség van arra, hogy a kérdések és a hozzájuk tartozó válaszok véletlenszerú sorrendben jelenjenek meg.

2. ábra: Példák a Google Forms programban készült interaktiv tesұt kérdéseiböl - számitógép hardver témakör (forrás: Zemanovic, 2019)

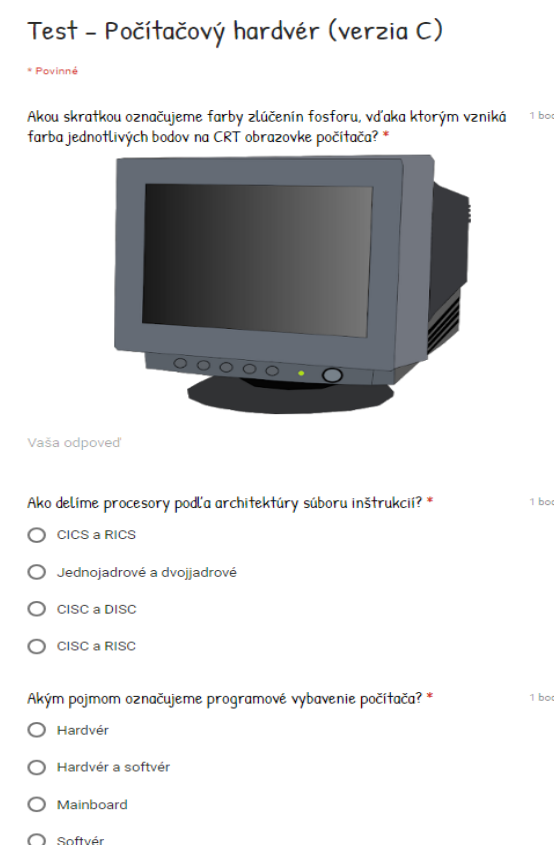

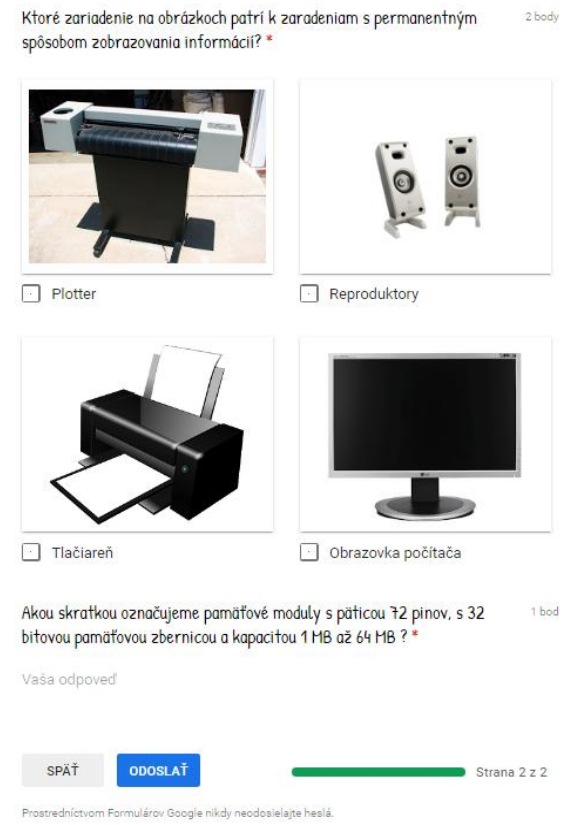

Képeket és videókat is hozzá lehet rendelni a kérdésekhez, és olyan fejlett funkciókat is lehet használni, mint például az elágazások és a kihagyási logika. Az egyes kérdésekhez válaszadási kötelezettséget lehet beállítani. A válaszok elküldése után a diák megtekintheti a saját teljes kitöltött tesztjét és a helyes válaszokat. 
Minden tesztrésztvevő elküldheti a kitöltött teszt másolatát személyes e-mail címére. A szoftver a válaszokat automatikusan elmenti, és ha szükséges, a tanár az eredményeket táblázatos formában exportálja a saját eszközére, vagy kinyomtathatja az eredményeket. Problémás válaszok esetén (például helyesírási vagy elírási hiba miatt a szoftver rossznak minősíti a szöveges választ) a tanárnak lehetősége van arra, hogy helyesnek igazolja a hallgató válaszát. A Google űrlapok segítségével elkészített tesztet a tanár elküldheti a válaszadóknak, és értékelheti a válaszokat.

A teszt létrehozásakor és értékelésénél a felhasználónak lehetôsége van további szolgáltatások (legtöbbjük ingyenes) telepítésére, amelyek hasznosak lehetnek a tesztelés során. Például a kérdés időzítése nem érhető el az ingyenes, online Google Forms szoftverben, de ingyenesen telepíthető a tesztbe a plug-in segítségével. Ahhoz azonban, hogy megfelelően múködjön, a tanárnak előre ismernie kell a hallgató e-mail címét.

\section{A teszt és a stressz}

Bármilyen fajta teszt eredményeit számos külsô és belső tényező befolyásolja, amelyek függenek egymástól. A külső tényezők közé tartozik például a teszt kidolgozásához megadott idő, a teszt formája, típusa, a vizsgálati módszer, amelyek a diákot a vizsgálat során befolyásolhatják. Az eredményeket befolyásoló belső tényezők között szerepel a diák fizikai és lelki állapota.

Ha a tanuló tudásszintjét mérjük, valójában teszteljük. Ha a diák elé tesztet teszünk azzal a kéréssel, hogy töltse ki, a tőle várható reakció, hogy kitölti, vagyis válaszol a tesztben feltett kérdésekre. Ez a tevékenysége azonban számos, nem specifikus kísérố reakciót tartalmazhat, amit stressznek nevezünk. A stresszmentes légkör fenntartásának érdekében, lehet segíthet a diákok tesztelési módjának a változtatása.

Az interaktív tábla, illetve az interaktív feladatok használata a tesztelésnél szintén hozzájárulhatnak a tesztelésből származó stressz csökkentéséhez, különösen akkor, ha a feladatok a megoldáshoz vala- milyen segitséget is nyújtanak. Még, ha tudja is a diák, hogy minden felhasznált segítség pontlevonással jár, akkor is nagyobb biztonságban érzi magát, mert bízik abban, hogy a segítséggel képes lesz megoldani a feladatokat.

Ha ezt az érzést még fokozzuk azzal, hogy a diák felmérve saját tudását maga válassza ki az interaktív teszt nehézségi szintjét, támogathatjuk benne az önértékelés képességét is. Ezt az elméleti feltevésünket megpróbáltuk egy egyszerú kísérlettel igazolni.

A kísérletben egy általános iskola negyedik osztályos tanulói vettek részt, szám szerint 40 . Három nehézségi fokú interaktív tesztet készítettünk, szlovák nyelv és irodalom tantárgyból (ez alapvetően nem releváns a kutatási tartalom szempontjából). A tesztek eredményeinek értékelése százalékosan történt.

A legalacsonyabb szintú tesztben a helyesen elvégzett feladatért 3,6\% járt. Ha a megoldásra a tanuló a rendelkezésre álló segítséget is felhasználta, akkor 1,8\% levonásra került. A maximálisan elérhető eredmény 75\% volt, ami a 3 (közepes) érdemjegynek felelt meg.

A következő nehézségi tesztben minden feladatért 4,4\% járt és a segítség használatáért 2,2\% levonás járt. A legmagasabb elérhető eredmény 89\% volt, ami 4 (jó) (a szlovák rendszer szerint 2 - dicséretes) érdemjegynek felelt meg.

A legnehezebb tesztben az elérhető eredmény $100 \%$ volt, ami 5 (jeles) (a szlovák rendszer szerint 1 - kiváló) érdemjegynek felelt meg. Minden helyes válaszért 5\% járt, segítség felhasználása esetén $2,5 \%$-kal csökkent.

A tesztelés elótt a tanuló kiválaszthatta a teszt nehézségi szintjét, attól függően, hogy az adott időpontban lelkileg hogyan érezte magát és hogyan értékelte az adott témával kapcsolatos ismereteit. Valójában a tanuló elóre meghatározta a feladatai nehézségi fokát, miközben tudomása volt arról, hogy milyen legmagasabb értékelést érhet el és ezt is figyelembe vette. A tanuló tisztában volt azzal, hogy amikor alacsonyabb tesztszintet választ, nem tudja a legjobb érdemjegyet elérni, még akkor sem, ha hibátlanul teljesít. Ha pedig a legmagasabb szintet 
választja, akkor a legjobb érdemjegyért nehezebb feladatokat kell majd megoldania, de itt is meglesz a lehetőség arra, hogy ha nem tudja megoldani a feladatot, vagy segítséget vesz igénybe, csökken az érdemjegy értéke. A választás lehetősége azonban csökkentheti a stresszt, és a diák tudásával megegyező teljesítményt érhető el.

A kísérletben részt vett tanulók 68\% az legmagasabb szintú interaktív tesztet választotta, $63 \%$-uk a legjobb eredményt érte el. Hasonló eredmények születtek a többi szinten is.

Azt tapasztaltuk, hogy ha a tanulók „tudatosságuk és lelkiismeretük" szerint választották tesztjük nehézségi szintjét, merészebbek, magabiztosabbak voltak, és többnyire a legjobb eredményt érték el az adott szinten. Ez a stressz csökkenésnek is köszönhető, mert olyan feladatokat vártak a tesztben, melyek megválaszolására elegendő tudással rendelkeztek.

A kísérleti eredmények alapján megállapítottuk, hogy ha a diákok maguk választják a tesztszintet, tekintettel saját vizsga előtti stressz érzésükre, vagy saját maguk által felbecsült tudásszintjükre, vagy más aktuális személyi okok miatt, akkor legtöbbször a kiválasztott szint legjobb eredményét érték el.

A választás lehetőségét az interaktív teszt különböző nehézségi szintjei közül, a tanulók tesztelésének pozitív módszerének tartjuk, mivel csökkenti a stresszt, a tanulók félelmét és feszültségét attól, hogy rossz érdemjegyet kapnak, támogatja önállóságukat, kreativitásukat és logikai gondolkodásukat. A tanulók a feladatokat nyugodtabban, felszabadultabban, természetessebben, kudarctól való félelem nélkül oldják meg. Ha az interaktív feladatokban a tanuló kihasználja a segédszövegeket, tudatosíthatja saját hiányosságait és lehetősége van pótolni azokat. A gyengébb tanulóknak lehetőségük van arra, hogy sikerélményben részesüljenek, ami kiváló motivációs tényező is. (Pšenáková és Szabó, 2018)

\section{Konklúzió}

$\mathrm{Az}$ elektronikus tesztelés legnagyobb előnye a tesztelési folyamat racionalizálása, mivel felgyorsul a visszajelzés a résztvevők felé, emellett pedig a pe- dagógusoknak könnyebb az eredmények feldolgozása is. Az interaktív feladatok és tesztek megtervezése, létrehozása és használata azonban magas követelményeket helyez a tanárok számára. A megfelelô szakértelem és a tesztek létrehozásával kapcsolatos pedagógiai és didaktikai ismeretek mel-lett, rendelkezniük kell bizonyos, számítógépek kezeléséhez szükséges ismeretekkel és készsé-gekkel, illetve el kell sajátítaniuk a megfelelő szoftver(ek) használatát is.

Annak ellenére, hogy vannak nagyon egyszerúen kezelhetô szoftvercsomagok, amelyek a pedagógusok rendelkezésére állnak az interaktív tesztek létrehozására és tudásvizsgálatok elvégzésére, a gyakorlatban még nem sok tanár használja az interaktív tesztelést. Ennek oka legtöbbször az, hogy nem tudnak jó, didaktikus és módszertani szempontból helyes interaktív tesztanyagot létrehozni.

Ezért fontosnak tartjuk, hogy a leendő pedagógusok képzésében meglegyen a helye az informatikai ismeretek bővebb elsajátításának és a számítógép és a pedagógus munkájához megfelelő szoftverek kezelésének elsajátítására is elegendő idôt tudjunk szentelni.

\section{Köszönetnyilvánítás}

A tanulmány a KEGA 015TTU-4/2018: „Interaktivita v elektronických didaktických aplikáciách.” (Interaktivitás az elektronikus didaktikai alkalmazásokban) címú projekt keretében készült.

\section{IRODALOM}

Burjan, V. (2003). Tvorba a využívanie školských testov. In Exam-info 1-7. Letöltés: 2019.04.08. Web: http://www.burjanoskole.sk/wpcontent/uploads/documents/Tvorba_testov_k omplet.pdf

Cápay, M. (2006). Výhody a nevýhody počítačového testovania. In Sietové a informačné technológie. Bratislava: ŠPÚ.

Csapó B., Molnár Gy., \& R. Tóth K. (2008). A papír alapú tesztektől a számítógépes adaptív tesztelésig: a pedagógiai mérés-értékelés technikájának fejlődési tendenciái. Iskolakultuira, 18 (34), 3-16. 
Ďuriš, M. \& Stadtrucker, R. (2013). Preverovanie vedomostí žiakov $\mathrm{v}$ odbornom predmete na strednej odbornej škole $s$ využitím PC. Edukacja-Technika-Informatyka., 4, 2. 57-66.

Godiš, T. (2017). Medien und Programme im Fremdsprachunterricht. In Jasykovedné, literárnovedné a didaktické kolokvium XLV.. Bratislava: Z-F Lingua,. ISBN 978-80-8177040-1. CD ROM, 35-51.

Pšenáková, I. (2016). Interactive applications in the work of teachers In XXIXth DIDMATTECH 2016. Eötvös Loránd University, Budapest.. 92-100.

Pšenáková, I., \& Szabó, T. (2018). Využitie interaktívnej tabule a interaktívnych úloh pri preverovaní vedomostí / In: Edukacja - tecbnika - informatyka w budowaniu lepszej praysztości. Radom: Wydawnictwo Uniwersytetu TechnologicznoHumanistycznego w Radomiu.. 151-159.

Pšenáková, I., Horváth, R., \& Szabó, T. (2016). Interaktívna tabul'a vo vzdelávaní budúcich pedagógov. Interactive whiteboard in the education of future teachers. In „Edukacja Technika - Informatyka" nr. 1/15/2016, Pol'sko, 224-229.

Stoffová, V. (2012). Algoritmy na precvičovanie zručností a na skúšanie a preverovanie vedomostí. In Nové technológie vo vede, výskume a v edukácii. - Brno: Librix. 179-195.

Zemanovič, D. (2019). Interaktivne testy pre predmet Počitačový hardvér - Diplomamunka. Témavezető: Pšenáková, I., Trnavská univerzita v Trnave. 